\title{
Male hypogonadism and pre-diabetes interplay: association or causal interaction? A systematic review
}

\author{
Carla Greco $^{1,2}$, Rossella Corleto ${ }^{1}$, Riccardo Ebert ${ }^{1}$, Manuela Simoni ${ }^{1,2}$, Vincenzo Rochira ${ }^{1,2}$, Daniele Santi ${ }^{1,2}$ \\ 'Unit of Endocrinology, Department of Biomedical, Metabolic and Neural Sciences, University of Modena and Reggio Emilia, \\ Modena 41100, Italy. \\ ${ }^{2}$ Unit of Endocrinology, Department of Medical Specialties, Azienda Ospedaliero-Universitaria di Modena, Ospedale Civile di \\ Baggiovara, Modena 41124, Italy.
}

Correspondence to: Dr. Vincenzo Rochira, MD, PhD, Department of Biomedical, Metabolic and Neural Sciences, University of Modena and Reggio Emilia, Modena 41100, Italy; Unit of Endocrinology, Department of Medical Specialties, Azienda Ospedaliero-Universitaria di Modena, Ospedale Civile di Baggiovara, Modena 41124, Italy. E-mail: vincenzo.rochira@unimore.it

How to cite this article: Greco C, Corleto R, Ebert R, Simoni M, Rochira V, Santi D. Male hypogonadism and pre-diabetes interplay: association or causal interaction? A systematic review. Metab Target Organ Damage 2022;2:11.

https://dx.doi.org/10.20517/mtod.2021.14

Received: 3 Oct 2021 First Decision: 27 Oct 2021 Revised: 15 Nov 2021 Accepted: 23 Nov 2021 Published: 2 Dec 2021

Academic Editor: Sonia M. Najjar Copy Editor: Yue-Yue Zhang Production Editor: Yue-Yue Zhang

\begin{abstract}
Aim: The association between type 2 diabetes mellitus (T2DM) and male hypogonadism has been largely demonstrated. Testosterone $(T)$ serum levels are often lower in men with T2DM compared to the general population, and, conversely, men with higher T serum levels have shown lower risk of T2DM. On the contrary, the association between pre-diabetes and male hypogonadism has been less investigated thus far. Pre-diabetes is a common clinical condition preceding T2DM and has been recognized as a potential risk factor for other metabolic disorders and cardiovascular diseases. Therefore, the aims of this review are to investigate the association between pre-diabetes and male hypogonadism and to evaluate the potential effect of T treatment on glucose metabolism and anti-diabetic therapy on T serum levels.
\end{abstract}

Methods: We conducted this systematic review developing different literature searches, following the Preferred Reporting Items for Systematic Reviews and Meta-Analysis protocol. 
Results: In our analysis, male hypogonadism has a prevalence of around 24\%-35\% in pre-diabetic men. Moreover, we observed improvement of metabolic parameters in pre-diabetes with $\mathrm{T}$ treatment. On the contrary, antidiabetic therapy seems to have no particular effects on $T$ serum levels.

Conclusion: Overall, we demonstrated that, although T administration could be considered in pre-diabetic men, pre-diabetes-related treatments should be confined to the control glucose metabolism, since no evidence for a positive effect on total T serum levels is available. Future research should be oriented to study the role of new antidiabetic drugs in the sex hormonal status in hypogonadal men.

Keywords: Hypogonadism, testosterone, pre-diabetes

\section{INTRODUCTION}

The association between diabetes mellitus (DM) and male hypogonadism has been largely claimed and proved $^{[1,2]}$. Indeed, testosterone $(\mathrm{T})$ deficiency and male hypogonadism are often found in patients with chronic metabolic diseases ${ }^{[3]}$. In the setting of type $2 \mathrm{DM}(\mathrm{T} 2 \mathrm{DM})$, $\mathrm{T}$ serum levels are lower in affected men compared to the general population ${ }^{[4]}$, and men with higher T levels $(7.4-15.5 \mathrm{nmol} / \mathrm{L})$ have shown a $42 \%$ lower risk of T2DM development ${ }^{[4]}$. A threshold of $16 \mathrm{nmol} / \mathrm{L}$ of $\mathrm{T}$ serum levels was described to potentially predict the T2DM onset ${ }^{[5]}$. Despite this evidence, the association between low $\mathrm{T}$ serum levels and the initial impairment of the glucose metabolism (i.e., pre-diabetes) is less clear and still debated.

The term "pre-diabetes" was introduced in 1997, indicating a condition in which glucose serum levels do not meet diagnostic criteria for T2DM but are too high to be considered normal ${ }^{[6]}$. Currently, pre-diabetes indicates a clinical condition characterized by: (1) impaired fasting glucose (IFG) (defined by a fasting glucose level between 100 and $125 \mathrm{mg} / \mathrm{dL}$ ); (2) impaired glucose tolerance (IGT) [defined by a glucose level between 140 and $199 \mathrm{mg} / \mathrm{dL} 2 \mathrm{~h}$ after receiving a $75 \mathrm{~g}$ oral glucose tolerance test (OGTT)]; or (3) glycated hemoglobin (HbA1c) level between 39 and $47 \mathrm{mmol} / \mathrm{mol}^{[6]}$. Despite these thresholds, the World Health Organization still considers $110 \mathrm{mg} / \mathrm{dL}$ as the upper reference limit for normal fasting glucose serum levels ${ }^{[7]}$. In line with international guidelines, pre-diabetes represents the buffer period before T2DM onset, during which impaired $\beta$-cell function and increased insulin resistance result in mild hyperglycemia ${ }^{[8]}$. The progression of pre-diabetes to frank T2DM is estimated to occur in up to $80 \%$ of the individuals with prediabetes $^{[8,9]}$. However, the natural history of pre-diabetes is extremely variable, although an increased coprevalence of metabolic syndrome, abdominal obesity, hypertension, and dyslipidemia is suggested ${ }^{[10,11]}$. Similarly, pre-diabetes seems to be related to microvascular changes-related comorbidities, such as nephropathy, neuropathy, retinopathy, erectile dysfunction, and obstructive sleep apnea ${ }^{[12-14]}$.

Male hypogonadism is a clinical condition characterized by reduced $\mathrm{T}$ and/or impaired spermatogenesis, usually associated with other signs and symptoms. The diagnosis of hypogonadism requires serum $\mathrm{T}$ levels lower than normal and confirmed twice, together with the presence of specific signs and symptoms ${ }^{[15,16]}$. Among hypogonadism-related symptoms, sexual dysfunction (i.e., reduced libido, reduced spontaneous or stimulated penile erection, and erectile dysfunction), hot flashes, reduced semen volume, and decreased hair in androgen-dependent areas are reported ${ }^{[17-19]}$. However, no validated serum $\mathrm{T}$ cutoff level exists, and different thresholds have been proposed by the guidelines of several international scientific societies ${ }^{[18,20-23]}$. Large epidemiological studies suggested that serum T levels below $12.1 \mathrm{nmol} / \mathrm{L}$ could be considered a diagnostic threshold to diagnose hypogonadism ${ }^{[24-27]}$. However, several authors suggested the occurrence of functional hypogonadism in middle-aged and older $\operatorname{men}^{[28]}$. This condition is assumed when clinical features compatible with androgen deficiency are present, without evidence of organic hypothalamicpituitary-testicular axis pathology ${ }^{[28]}$. 
Considering the association between endogenous sex hormones and glucose metabolism, longitudinal and population-based studies confirmed the $\mathrm{T}$ reduction in overweight/obese men, who, in turn, are more susceptible to develop $\mathrm{T}_{2} \mathrm{DM}^{[29-33]}$. Accordingly, low serum $\mathrm{T}$ levels increase the risk of insulin resistance independently of age ${ }^{[34-36]}$, and $\mathrm{T}$ is directly related to insulin sensitivity ${ }^{[37]}$. Moreover, insulin resistance is found to be associated with reduced serum levels of total $\mathrm{T}$ and sex hormone binding globulin (SHBG) ${ }^{[38-40]}$. However, the cause-effect relationship direction linking endogenous sex hormones and impaired glucose metabolism remains to be clarified. Indeed, the main evidence in favor to this link simply identifies that low $\mathrm{T}$ levels are associated with higher $\mathrm{T} 2 \mathrm{DM}$ risk $^{[4,41]}$, but which of $\mathrm{T}$ reduction or alteration of glucose metabolism occurs first in these patients is yet to be defined.

\section{Effects of exogenous testosterone on glucose metabolism}

In this intriguing glucose-androgen crosstalk, several issues remain to be solved. The effects of $\mathrm{T}$ therapy on glucose metabolism have been investigated in some studies ${ }^{[42]}$. T administration in euglycemic men leads to a lean body mass increase, together with a reduction in fat mass, with a favorable net metabolic effect ${ }^{[43,44]}$. In particular, the comprehensive evaluation of existing data reveals that androgen therapy leads to a total body fat mass reduction and fat-free mass increase, together with a small decrease in total cholesterol ${ }^{[45]}$. Similarly, a potential glucose metabolism improvement after androgen replacement therapy is suggested in diabetic $\mathrm{men}^{[46-48]}$. Indeed, $\mathrm{T}$ replacement therapy reduced $\mathrm{HbA1c}$, fasting plasma glucose levels, and homeostasis model assessment of insulin resistance (HOMA-IR) in T2DM subjects ${ }^{[49]}$. Briefly, 90\% of T2DM patients achieved an $\mathrm{HbA} 1 \mathrm{c}$ of less than $7 \%$, and $34 \%$ had total $\mathrm{T} 2 \mathrm{DM}$ remission ${ }^{[49]}$. Thus, it seems clear that treating male hypogonadism could have significant metabolic effects, useful to prevent or improve glucose metabolism dysregulation. These effects could be explained by the inhibitory action of $\mathrm{T}$ on the incorporation of dietary fat into adipose tissue, especially intra-abdominal fat ${ }^{[49]}$. Male subjects receiving $250 \mathrm{mg}$ of $\mathrm{T}$ intramuscularly five days prior to abdominal surgery showed a significant reduction in the amount of labeled omental and retroperitoneal fat ${ }^{[50]}$. Moreover, in vitro experiments showed that $\mathrm{T}$ suppresses adipocytic differentiation of preadipocytes, activating the Wnt pathway with an increased expression of $\beta$-catenin ${ }^{[51]}$. Moreover, T seems to promote the conversion of mesenchymal pluripotent stem cells into myogenic lineage and inhibit their conversion to adipocytes ${ }^{[52]}$. Although these mechanisms have yet to be confirmed in humans, they contribute to the T-related loss of adiposity, through increased oxidation of fatty acids by the skeletal muscle ${ }^{[42]}$. International guidelines for the management of male hypogonadism suggest starting androgen replacement therapy when $\mathrm{T}$ serum levels are low (i.e., below $8 \mathrm{nmol} / \mathrm{L}$ ) or slightly reduced in the case of hypogonadism-related symptoms, particularly decreased morning erections, limitation in vigorous activity, and fatigue ${ }^{[16]}$. Thus, the evidence available suggests starting androgen replacement therapy in men with T2DM and low or only slightly reduced T serum level ${ }^{[18]}$. The question remains whether these treatments should be considered also in the case of prediabetes.

\section{Effects of T2DM treatment on testosterone levels}

Weight loss by lifestyle intervention is the cornerstone treatment for T2DM and still represents the first-line approach. In this setting, diet-induced weight loss is demonstrated to also have a modest reversal effect on total $\mathrm{T}$ serum levels in diabetic men $^{[53]}$. Moreover, some of the anti-diabetic drugs currently used in T2DM seem to influence $\mathrm{T}$ serum levels in an experimental setting ${ }^{[54,55]}$. Thus, a potential action of T2DM-related therapies on hypogonadism could be expected. However, whether these therapeutic approaches are really useful in pre-diabetic men with hypogonadism is still controversial.

Collectively, it seems clear that T2DM and male hypogonadism are strictly associated, and, when coexisting, both disease-specific therapeutic approaches should be considered. The first aim of this review is to evaluate the evidence available in the literature, combining male hypogonadism and pre-diabetes. Then, our 
goal is to evaluate the potential effect of hypogonadism and anti-diabetic therapies on glucose metabolism and $\mathrm{T}$ serum levels, respectively.

\section{METHODS}

This systematic review was conducted developing three different literature searches, following the Preferred Reporting Items for Systematic Reviews and Meta-Analysis protocol [Supplementary Material]. The first literature search was conducted to evaluate the prevalence of male hypogonadism in pre-diabetes and vice versa. The second search was done to evaluate the effect on glucose metabolism of androgen replacement treatment in male hypogonadism. Finally, a third literature search evaluated the effect of pre-diabetes treatment on endogenous $\mathrm{T}$ serum levels.

\section{Data sources and search strategies}

We identified original research papers by searching MEDLINE and EMBASE until May 20, 2021. Terms used for the first literature search were: "male hypogonadism", "testosterone", "pre-diabetes", "impaired fasting glucose (IFG)", and "impaired glucose tolerance (IGT)". In the second search, the following terms were used: "androgen replacement therapy", "testosterone", "male hypogonadism", "pre-diabetes", "impaired fasting glucose (IFG)", and "impaired glucose tolerance (IGT)". Finally, the third search was performed using the terms: "lifestyle", "antidiabetic drugs", "metformin", "male hypogonadism", "prediabetes", "impaired fasting glucose (IFG)", and "impaired glucose tolerance (IGT)". These terms were intentionally chosen to be broad to increase sensitivity and capture all relevant studies and were mixed with Boolean functions "AND" and "OR". Only studies in English were considered.

\section{Study selection}

All study designs were considered eligible, and both observational and interventional studies were considered. The following criteria were considered. In the first literature search, papers must report the percentage of patients with male hypogonadism and with pre-diabetes. For the second search, we considered studies in which (1) hypogonadal men (2) were treated with exogenous testosterone and (3) blood glucose levels were reported. For the third search, only studies enrolling (1) patients with prediabetes; (2) treated for pre-diabetes; and (3) in whom T serum levels were reported were considered eligible. For all three literature selections, it was required that the study reported the criteria used for the definition of both male hypogonadism and pre-diabetes.

\section{Data extraction}

Two authors (Corleto R and Ebert R) independently searched databases, extracted works, and reviewed titles and abstracts. Data were independently extracted from the included studies using a standardized Excel form. The following parameters were extracted for each manuscript: author, journal, year of publication, study design, aim of the study, inclusion criteria, male hypogonadism and pre-diabetes diagnostic criteria used, number of patients enrolled, and patients' age, body mass index (BMI), androgen replacement therapies, T2DM-related therapies, T serum levels, and glucose serum levels.

\section{Data synthesis and analysis}

A meta-analytic approach was added when more than three case-control studies were detected. When the same author published different works on the same cohort, only the most recent one was included in the meta-analysis. Using the Review Manager (RevMan) 5.4 Software (Version 5.4.1 Copenhagen: The Nordic Cochrane Centre, The Cochrane Collaboration, 2014), continuous variables were comprehensively evaluated as inverse variance of mean variables. When data were reported in the original manuscript as median or logarithm, they were transformed in mean \pm standard deviation. However, since these parameters could be obtained using different approaches, the meta-analyses were performed using standard 


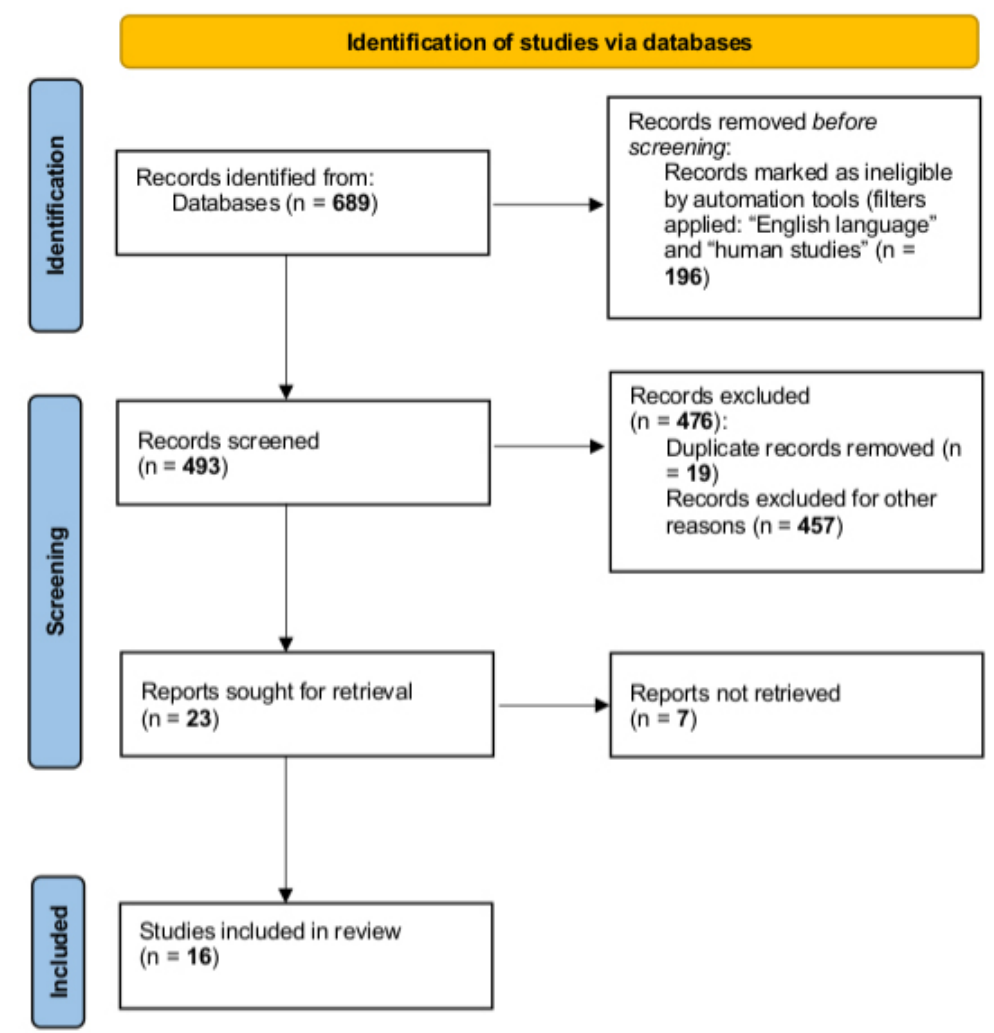

First search, performed on databases MEDLINE and EMBASE until May 20, 2021, using the terms "male hypogonadism",

"testosterone", "prediabetes", "IFG", "impaired fasting glucose", "IGT", "impaired glucose tolerance".

Figure 1. Flow chart of the first literature search.

mean difference. The degree of heterogeneity among the studies included in each analysis was examined by inspecting both the scatter in the data points and the overlap in their confidence intervals (CIs), as well as by performing $\mathrm{I}^{2}$ statistics. The inverse variance with the fixed model was initially chosen, whereas the random effect model was preferred in the case of $\mathrm{I}^{2}$ higher than $60 \%$.

\section{RESULTS}

\section{Male hypogonadism prevalence in pre-diabetes}

Considering the first literature search, 16 cross-sectional studies were retrieved [Figure 1], reporting either total $\mathrm{T}$ serum levels or hypogonadism prevalence in men with pre-diabetes [Table 1]. The mean hypogonadism prevalence was $29 \%$, ranging from $30 \%$, when $\mathrm{T}$ below $12 \mathrm{nmol} / \mathrm{L}$ was considered as diagnostic threshold ${ }^{[5]}$, to $24.1 \%-34.8 \%$, when hypogonadism was defined by total serum $\mathrm{T}$ levels lower than $10.4 \mathrm{nmol} / \mathrm{L}^{[57-60]}$. Overall, pre-diabetic men showed significantly $(P=0.002)$ higher BMI compared to euglycemic controls [Supplementary Figure 1], whereas no difference $(P=0.870)$ in patients' age was found [Supplementary Figure 2].

In eleven studies, pre-diabetic patients were compared to euglycemic controls. Overall, total $\mathrm{T}$ serum levels were significantly lower (of about $2.90 \mathrm{nmol} / \mathrm{L}$; $95 \% \mathrm{CI}: 1.01-3.60 \mathrm{nmol} / \mathrm{L}$ ) in pre-diabetic men compared to euglycemic controls, applying a meta-analytic approach $(P<0.001)$ [Figure 2]. Moreover, some of these studies tried to distinguish pre-diabetes in IFG and IGT. Goodman-Gruen et al. ${ }^{[61]}$ evaluated 266 prediabetic subjects, highlighting either total $\mathrm{T}$ serum levels or bioavailable $\mathrm{T}$ serum levels lower in IFG 
Table 1. Characteristics of studies considered in the first literature search: male hypogonadism prevalence in pre-diabetes. Data are expressed as mean 4 standard deviation

\begin{tabular}{|c|c|c|c|c|c|c|c|c|c|}
\hline \multirow{2}{*}{ Author, year } & \multirow{2}{*}{ Aim of the study } & \multicolumn{2}{|c|}{ Diagnostic criteria } & \multicolumn{3}{|c|}{ Pre-diabetic } & \multicolumn{3}{|c|}{ Controls } \\
\hline & & Hypogonadism & Pre-diabetes & Subjects & BMI $\left(\mathrm{kg} / \mathrm{m}^{2}\right)$ & Age (years) & Subjects & BMI $\left(\mathrm{kg} / \mathrm{m}^{2}\right)$ & Age (years) \\
\hline $\begin{array}{l}\text { Goodman-Gruen et al. }{ }^{[61]}, \\
2000\end{array}$ & $\begin{array}{l}\text { To evaluate sex differences in the } \\
\text { association between endogenous } \\
\text { estrogen and testosterone levels and } \\
\text { glucose tolerance status }\end{array}$ & NA & $\begin{array}{l}\text { FPG } 100-126 \mathrm{mg} / \mathrm{dL} \\
2 \mathrm{~h} \text { OGTT } 140-199 \mathrm{mg} / \mathrm{dL}\end{array}$ & $\begin{array}{l}\text { IFG } 60 \\
\text { IGT } 206\end{array}$ & $\begin{array}{l}\text { IFG } 26.7 \pm 2.8 \\
\text { IGT } 25.7 \pm 3.3\end{array}$ & $\begin{array}{l}\text { IFG } 68.6 \pm 8.5 \\
\text { IGT } 74.2 \pm 7.5\end{array}$ & 397 & $25.8 \pm 3.3$ & $70.5 \pm 8.6$ \\
\hline Colangelo et al. ${ }^{[63]}, 2009$ & $\begin{array}{l}\text { To assess associations of sex hormones } \\
\text { with IFG and T2DM in men }\end{array}$ & NA & FPG: $100-126 \mathrm{mg} / \mathrm{dL}$ & 1046 & NA & NA & NA & NA & NA \\
\hline Corona et al. ${ }^{[12]}, 2012$ & $\begin{array}{l}\text { To evaluate the impact of IFG on sexual } \\
\text { health in men }\end{array}$ & $\mathrm{TT}<8 \mathrm{nmol} / \mathrm{L}$ & FPG: $100-125$ mg/dL & 659 & $28.6 \pm 5.0$ (all) & $58.5 \pm 9.7$ (all) & 2045 & NA & NA \\
\hline Ho et al. ${ }^{[59]}, 2013$ & $\begin{array}{l}\text { To investigate whether pre-diabetes was } \\
\text { associated with an increased risk of } \\
\text { testosterone deficiency }\end{array}$ & $\mathrm{TT}<10.4 \mathrm{nmol} / \mathrm{L}$ & $\begin{array}{l}\text { FPG: } 100-125 \mathrm{mg} / \mathrm{dL} \\
2 \mathrm{~h} \text { OGTT } 140-199 \mathrm{mg} / \mathrm{dL} \\
\mathrm{HbA1c} 39-46 \mathrm{mmol} / \mathrm{mol}\end{array}$ & 543 & $25.2 \pm 3.1$ & $55.8 \pm 8.5$ & 577 & $24.4 \pm 3.0$ & $52.6 \pm 8.6$ \\
\hline Chen et al. ${ }^{[65]}, 2014$ & $\begin{array}{l}\text { To investigate the associations of serum } \\
\text { total osteocalcin and undercarboxylated } \\
\text { osteocalcin with glucose and lipid } \\
\text { metabolism }\end{array}$ & NA & $\begin{array}{l}\text { FPG: } 100-125 \mathrm{mg} / \mathrm{dL} \\
2 \text { h OGTT } 140-200 \mathrm{mg} / \mathrm{dL}\end{array}$ & 52 & $27.6 \pm 1.0$ & $50.0 \pm 10.0$ & 46 & $26.3 \pm 4.8$ & $48.0 \pm 10.0$ \\
\hline Rabijewski et al. ${ }^{[56]}, 2015$ & $\begin{array}{l}\text { To investigate the prevalence of } \mathrm{LOH} \text { in } \\
\text { men with pre-diabetes }\end{array}$ & $\begin{array}{l}\mathrm{TT}<12 \mathrm{nmol} / \mathrm{L} \text { or } \\
\text { calculated free } \mathrm{T}< \\
0.25 \mathrm{nmol} / \mathrm{L}\end{array}$ & $\begin{array}{l}\text { FPG: } 100-125 \mathrm{mg} / \mathrm{dL} \\
2 \mathrm{~h} \text { OGTT } 140-200 \mathrm{mg} / \mathrm{dL} \\
\mathrm{HbA} 1 \mathrm{c} 39-46 \mathrm{mmol} / \mathrm{mol}\end{array}$ & 196 & $29.6 \pm 1.5$ & $68.4 \pm 3.1$ & 184 & $27.1 \pm 0.9$ & $65.8 \pm 3.4$ \\
\hline Arthur et al. ${ }^{[40]}, 2016$ & $\begin{array}{l}\text { To investigate whether serum sex } \\
\text { steroid hormone concentrations differ } \\
\text { between men with and without pre- } \\
\text { diabetes }\end{array}$ & NA & $\begin{array}{l}\text { FPG: } 100-125 \mathrm{mg} / \mathrm{dL} ; \\
2 \mathrm{~h} \text { OGTT } 140-199 \mathrm{mg} / \mathrm{dL} \\
\mathrm{HbA} 1 \mathrm{c} 39-46 \mathrm{mmol} / \mathrm{mol}\end{array}$ & 411 & $27.5 \pm 12.2$ & $38.3 \pm 12.2$ & 728 & $25.4 \pm 5.4$ & $47.5 \pm 32.4$ \\
\hline Rabijewski et al. ${ }^{[46]}, 2016$ & $\begin{array}{l}\text { To investigate the relationships between } \\
\text { anabolic hormones and body } \\
\text { composition in middle-aged and elderly } \\
\text { men with pre-diabetes }\end{array}$ & $\mathrm{TT}<12 \mathrm{nmol} / \mathrm{L}$ & $\begin{array}{l}\text { FPG: } 100-125 \mathrm{mg} / \mathrm{dL} \\
2 \mathrm{~h} \mathrm{OGTT} 140-200 \mathrm{mg} / \mathrm{dL} \\
\mathrm{HbA1c} 39-46 \mathrm{mmol} / \mathrm{mol}\end{array}$ & 84 & $28.6 \pm 1.2$ & $66.5 \pm 3.8$ & 58 & $27.8 \pm 0.9$ & $65.7 \pm 3.8$ \\
\hline Zhu et al. ${ }^{[60]}, 2016$ & $\begin{array}{l}\text { To investigate whether androgens were } \\
\text { associated with the prevalence of pre- } \\
\text { diabetes in men }\end{array}$ & NA & $\begin{array}{l}\text { FPG: } 100-125 \mathrm{mg} / \mathrm{dL} \\
2 \mathrm{~h} \text { OGTT } 140-200 \mathrm{mg} / \mathrm{dL} \\
\mathrm{HbA} 1 \mathrm{c} 39-46 \mathrm{mmol} / \mathrm{mol}\end{array}$ & 907 & $24.7 \pm 26.3$ & $57.3 \pm 10.4$ & 1405 & $24.1 \pm 31.7$ & $45.5 \pm 8.2$ \\
\hline Boeri et al. ${ }^{[57]}, 2018$ & $\begin{array}{l}\text { To assess the association between pre- } \\
\text { diabetes and erectile function in men } \\
\text { with ED }\end{array}$ & $\mathrm{TT}<10.4 \mathrm{nmol} / \mathrm{L}$ & $\begin{array}{l}\text { FPG: } 100-125 \mathrm{mg} / \mathrm{dL} ; \\
2 \mathrm{~h} \text { OGTT } 140-199 \mathrm{mg} / \mathrm{dL} \\
\text { HbA1c } 39-46 \mathrm{mmol} / \mathrm{mol}\end{array}$ & 86 & $25.9 \pm 4.7$ & $56.9 \pm 10.7$ & 286 & $25.1 \pm 3.4$ & $54.2 \pm 13.4$ \\
\hline Lu et al. ${ }^{[62]}, 2018$ & $\begin{array}{l}\text { To investigate the relationship of } \\
\text { testosterone and different glucose } \\
\text { tolerance state, and its association with } \\
\text { osteocalcin }\end{array}$ & NA & $\begin{array}{l}\text { FPG: } 100-125 \mathrm{mg} / \mathrm{dL} \\
2 \mathrm{~h} \text { OGTT } 140-200 \mathrm{mg} / \mathrm{dL} \\
\mathrm{HbA1c} 39-46 \mathrm{mmol} / \mathrm{mol}\end{array}$ & 495 & $24.6 \pm 2.8$ & $77.2 \pm 9.1$ & 545 & $24.4 \pm 2.8$ & $73.6 \pm 9.2$ \\
\hline Boeri et al. ${ }^{[58]}, 2019$ & $\begin{array}{l}\text { To study the prevalence and the risk } \\
\text { associated with pre-diabetes in primary } \\
\text { infertile men }\end{array}$ & $\mathrm{TT}<10.4 \mathrm{nmol} / \mathrm{L}$ & $\begin{array}{l}\text { FPG:100-125 mg/dL } \\
2 \text { h OGTT } 140-199 \mathrm{mg} / \mathrm{dL} \\
\mathrm{HbA} 1 \mathrm{c} 39-46 \mathrm{mmol} / \mathrm{mol}\end{array}$ & 114 & $26 \pm 2.5$ & $40.4 \pm 6$ & 630 & $25.3 \pm 2.8$ & $38 \pm 4.5$ \\
\hline
\end{tabular}




\begin{tabular}{|c|c|c|c|c|c|c|c|c|c|}
\hline Boeri et al. ${ }^{[58]}, 2019$ & $\begin{array}{l}\text { To assess rates of and predictors of } \\
\text { response to oral treatment in a cohort of } \\
\text { ED men naïve for PDE5i with normo- } \\
\text { glycemia, Pre-DM, or diabetes mellitus }\end{array}$ & $\mathrm{TT}<10.4 \mathrm{nmol} / \mathrm{L}$ & $\begin{array}{l}\text { FPG:100-125 mg/dL } \\
2 \text { h OGTT } 140-199 \mathrm{mg} / \mathrm{dL} \\
\text { HbA1c } 39-46 \mathrm{mmol} / \mathrm{mol}\end{array}$ & 105 & $26 \pm 11.4$ & $58.2 \pm 34.9$ & 253 & $25.2 \pm 14.9$ & $50.2 \pm 82.8$ \\
\hline Liu et al. ${ }^{[64]}, 2019$ & $\begin{array}{l}\text { To investigate the association of serum } \\
\text { testosterone with IFG and T2DM and } \\
\text { calculate the proportion explained by } \\
\text { obesity status on the relationship }\end{array}$ & NA & $\begin{array}{l}\text { FPG } 110-125 \mathrm{mg} / \mathrm{dL} ; \\
\mathrm{HbA1C} 39-46 \mathrm{mmol} / \mathrm{mol}\end{array}$ & 355 & $24.2 \pm 3.3$ & $59.9 \pm 9.0$ & 355 & $23.1 \pm 3.1$ & $59.8 \pm 9.0$ \\
\hline
\end{tabular}

BMI: Body mass index; DM: diabetes mellitus; ED: erectile disfunction; FPG: fasting plasma glucose; HbA1c: hemoglobin glycated; IFG: impaired fasting glucose; IGT: impaired glucose tolerance; LOH: late-onset hypogonadism; NA: not available; OGTT: oral glucose tolerance test; PDE5i: phosphodiesterase- 5 inhibitors; T2DM: type 2 diabetes mellitus; TT: total testosterone.

compared to controls and IGT. This large population-based study confirmed that men with IFG and IGT have reduced total T serum levels, similarly to T2DM, regardless of total body fat, body fat distribution, physical activity, and smoking ${ }^{[6]}$. This result, although interesting, is partly in contrast with a previous work of Rabijewski et al. ${ }^{[46]}$, which reported lower T in IGT compared to IFG patients. In this scenario, Corona et al. ${ }^{[12]}$ detected a stepwise increase in hypogonadism prevalence as a function of glucose abnormalities. Similarly, Lu et al ${ }^{[62]}$ reported a direct correlation between glucose tolerance status impairment and serum $\mathrm{T}$ decrease. Again, Colangelo et al. ${ }^{[63]}$ observed a significant inverse association between total T serum levels and IFG, and similar results were also reported by Liu et al. ${ }^{[64]}$. Zhu et al ${ }^{[60]}$ confirmed lower T in pre-diabetic compared to euglycemic men, highlighting an inverse relationship between $\mathrm{T}$ and pre-diabetes by multinomial and logistic regression analyses. Some other biochemical or anthropometric parameters were found to be significantly different between pre-diabetic and non-pre-diabetic patients. Despite this extensive demonstration of reduced total T serum levels in pre-diabetic men, some studies detected only a slight, but not statistically significant, increase of T levels in pre-diabetes compared to euglycemic controls ${ }^{[65]}$. However, it is suggested that low $\mathrm{T}$ concentrations in men are associated with progression from normoglycemia to pre-diabetes, but not from pre-diabetes to diabetes ${ }^{[6]}$.

SHBG serum levels were available in nine studies ${ }^{[12,40,46,5,5,58,60,62,63]}$. Arthur et al. ${ }^{[40]}$ and Boeri et al. ${ }^{[58]}$ reported significantly lower SHBG levels in pre-diabetic patients compared to controls. Similarly, a significant, inverse correlation between SHBG and glucose homeostasis was detected in pre-diabetic men ${ }^{[12]}$ as well as in the subgroup of patients with $\mathrm{IFG}^{[1] 1}$. However, five studies reported lower SHBG concentrations in euglycemic controls compared to pre-diabetic patients, leaving the association between SHBG serum levels and pre-diabetes unclear ${ }^{[4,56,57,60,62]}$. In particular, Zhu et al. ${ }^{[60]}$ highlighted low SHBG as an independent predictor of pre-diabetes incidence, especially in elderly men and irrespective of total $\mathrm{T}$ serum levels.

Finally, estradiol serum levels were reported in eight studies, showing a significant direct relationship with IFG ${ }^{[12,40,46,56-58,61-63]}$. In detail, estradiol serum levels were significantly lower in pre-diabetic patients compared to controls in three studies ${ }^{[4,56,58]}$, whereas five studies did not detect any significant difference $e^{[40,57,61,62]}$. 


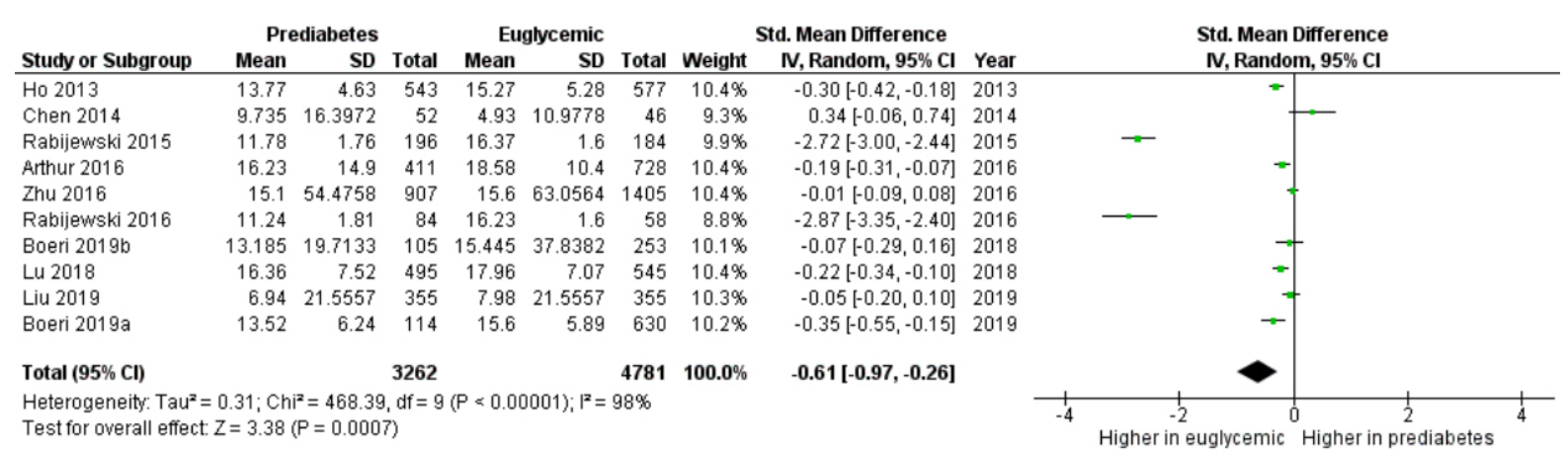

Figure 2. Forest plot reports total T serum levels comparing pre-diabetic men with controls.

\section{Pre-diabetes prevalence in male hypogonadism}

Considering still the first literature search, two studies reported the pre-diabetes prevalence in male hypogonadism [Figure 1 and Table 2]. Rabijewski et al. ${ }^{[67]}$ showed that hypogonadal men were older, with higher BMI and waist circumference compared to euglycemic controls. In this cohort, pre-diabetes prevalence was higher in hypogonadal patients $(41.5 \%)$ than in controls $(13 \%)^{[67]}$. Among hypogonadal patients, serum $\mathrm{T}$ was significantly lower in patients with pre-diabetes compared to euglycemic controls, and patients with IGT had significantly lower T than the subgroups with IFG and elevated HbA1c. Similarly, Pitteloud et al. ${ }^{[37]}$ detected a slightly higher pre-diabetes prevalence in hypogonadal than eugonadal men ( $30 \% v$ s. $18 \%$, respectively), showing that hypogonadal patients were more insulin resistant than their eugonadal counterparts (insulin sensitivity $=3.6 \pm 0.6 \mathrm{mg} \cdot \mathrm{kg}^{-1} \cdot \mathrm{min}^{-1} v s .7 .3 \pm 3 \mathrm{mg} \cdot \mathrm{kg}^{-1} \cdot \mathrm{min}^{-1}$, respectively; $P<0.007)$.

\section{Effects of androgen-replacement therapy on glucose metabolism in pre-diabetic males}

Considering the second literature search [Figure 3], only three studies were retrieved. Wittert et al. ${ }^{[48]}$ performed a randomized, double-blind, placebo-controlled, phase $3 \mathrm{~b}$ trial, treating men with hypogonadism and impaired glucose tolerance and proving that $\mathrm{T}$ treatment for two years can prevent progression to $\mathrm{T} 2 \mathrm{DM}$ or reverse early T2DM, beyond the effects of a lifestyle program. Even though the authors considered patients with early T2DM (20\%) and pre-diabetes (80\%) together, it is possible to estimate a similar effect in both in reducing the proportion of participants T2DM after T treatment showing OGTT normalized in $43 \%$ and $52 \%$ in control and study groups, respectively ${ }^{[48]}$. Krysiak et al. ${ }^{[68]}$ treated 14 hypogonadal-IGT men with a combination of metformin ( $1.7 \mathrm{~g}$ daily) and oral T undecanoate (120 mg daily) for 24 weeks [Table 3]. As expected, $\mathrm{T}$ significantly improved after 24 weeks of $\mathrm{T}$ administration compared to baseline and patients treated with metformin alone ${ }^{[68]}$. Moreover, serum glucose levels at 120 min during OGTT were significantly reduced after 24 weeks of combined metformin and T therapy compared to baseline, although no significant differences were observed compared to metformin alone ${ }^{[68]}$.

Yassin et al.$^{[6]]}$ followed 229 hypogonadal men with pre-diabetes receiving parenteral $\mathrm{T}$ undecanoate (1000 mg every 12 weeks) over eight years. Total $\mathrm{T}$ levels normalized after the first injection ${ }^{[6]]}$. Fasting glucose and $\mathrm{HbA} 1 \mathrm{c}$ were significantly lower in the treated compared to the control group throughout the entire follow up ${ }^{[69]}$. Fasting blood glucose and $\mathrm{HbA} 1 \mathrm{c}$ were reduced in the $\mathrm{T}$ group and increased in the control group at eight years ${ }^{[6]}$. All treated patients showed $\mathrm{HbA} 1 \mathrm{c}$ below $48 \mathrm{mmol} / \mathrm{mol}$ at eight years and 205 patients had $\mathrm{HbA1c}$ lower than $39 \mathrm{mmol} / \mathrm{mol}$, achieving normal glucose control, while $40.2 \%$ in the untreated group developed $\mathrm{T} 2 \mathrm{DM}^{[69]}$. 
Table 2. Characteristics of studies considered in the first literature search: male hypogonadism prevalence in pre-diabetes and pre-diabetes prevalence in male hypogonadism. Data are expressed as mean 4 standard deviation

\begin{tabular}{|c|c|c|c|c|c|c|c|c|c|}
\hline \multirow[b]{2}{*}{ Author, year } & \multirow[b]{2}{*}{ Aim of the study } & \multicolumn{2}{|c|}{ Diagnostic criteria } & \multicolumn{3}{|c|}{ Hypogonadal } & \multicolumn{3}{|c|}{ Eugonadal con-trols } \\
\hline & & Hypogonadism & Pre-diabetes & Subjects & $\left(\mathrm{Bg} / \mathrm{m}^{2}\right)$ & $\begin{array}{l}\text { Age } \\
\text { (years) }\end{array}$ & Subjects & $\left(\mathrm{kg} / \mathrm{m}^{2}\right)$ & $\begin{array}{l}\text { Age } \\
\text { (years) }\end{array}$ \\
\hline $\begin{array}{l}\text { Pitteloud et al. }{ }^{[35]}, \\
2005\end{array}$ & $\begin{array}{l}\text { To examine the relationship between serum testosterone } \\
\text { levels and insulin sensitivity and mitochondrial function in } \\
\text { men }\end{array}$ & $\mathrm{TT}<9.7 \mathrm{nmol} / \mathrm{L}$ & 2 h OGTT $140-200$ mg/dL & 10 & $32 \pm 2$ & $57 \pm 3.5$ & 50 & $26 \pm 0.5$ & $61 \pm 1$ \\
\hline $\begin{array}{l}\text { Rabijewski et al. }{ }^{[67]}, \\
2014\end{array}$ & $\begin{array}{l}\text { To investigate the prevalence of pre-diabetes in men with } \\
\mathrm{LOH}\end{array}$ & $\begin{array}{l}\mathrm{TT}<12 \mathrm{nmol} / \mathrm{L} \text { or calculated } \\
\text { free } \mathrm{T}<0.25 \mathrm{nmol} / \mathrm{L}\end{array}$ & $\begin{array}{l}\text { FPG: } 100-125 \mathrm{mg} / \mathrm{dL} \\
2 \mathrm{~h} \text { OGTT } 140-200 \mathrm{mg} / \mathrm{dL} \\
\mathrm{HbA} 1 \mathrm{c} 39-46 \mathrm{mmol} / \mathrm{mol}\end{array}$ & 246 & $32.4 \pm 1.4$ & $67.3 \pm 3.2$ & 184 & $27.6 \pm 1.2$ & $65.8 \pm 3.4$ \\
\hline
\end{tabular}

BMI: Body mass index; FPG: fasting plasma glucose; HbA1c: hemoglobin glycated; LOH: late-onset hypogonadism; OGTT: oral glucose tolerance test; TT: total testosterone.

Strollo et al. ${ }^{[70]}$ treated 48 overweight patients with hypogonadism and IFG with oral, transmucosal, and transdermal T formulations for six months. Metabolic parameters, such as fasting glucose levels and HOMA-IR, improved after treatment, with a greater reduction with transmucosal and transdermal deliveries, compared to oral formulations ${ }^{[70]}$.

\section{Effects of anti-diabetic treatment on male hypogonadism}

Considering the third literature search [Figure 4], only two studies were retrieved. Krysiak et al. ${ }^{[71]}$ evaluated 29 pre-diabetic men, 10 with hypergonadotropic hypogonadism and 19 with normal total T serum levels, treated with metformin (2.55-3 g/daily) for 16 weeks [Table 4]. The treatment significantly reduced fasting glucose and $\mathrm{HbA1c}$ in both groups, with lower values in hypogonadal compared to eugonadal men ${ }^{[7]}$. Total $\mathrm{T}$ serum levels did not significantly change after 16 weeks of treatment in both groups, although a significant gonadotropin decrease was detected in hypogonadal men ${ }^{[7]}$. This result is consistent with a previous study in which 14 hypogonadal-IGT men were treated with metformin for 16 weeks ${ }^{[68]}$. Glucose tolerance assessed by OGTT significantly improved after treatment, without improvement of total $\mathrm{T}$ serum levels ${ }^{[68]}$.

\section{DISCUSSION}

According to our review of the literature, male hypogonadism has a prevalence of around 24\%-35\% in pre-diabetic men. Indeed, total T serum levels are lower in pre-diabetic patients compared to healthy controls, confirming that $\mathrm{T}$ decrease is a characteristic of pre-diabetes as well as T2DM. However, the exact timing of the $\mathrm{T}$ decline in the natural history of pre-diabetes/T2DM is still not fully understood. Considering the pathophysiology of pre-diabetes and the role of increased body fat and insulin resistance, a higher prevalence of hypogonadism could be expected in IFG compared to IGT. This correlation was detected in some but not all studies. Indeed, some authors detected a reduction of serum total T levels more evident in IGT than in IFG pre-diabetic patients. In particular, total T serum levels in pre-diabetic patients seemed to be related to the glycemic control, although it is not clear whether a threshold of glucose metabolism impairment resulting in $\mathrm{T}$ reduction exists. This contrasting result confirms the need to perform an accurate evaluation of both metabolic and hormonal status 


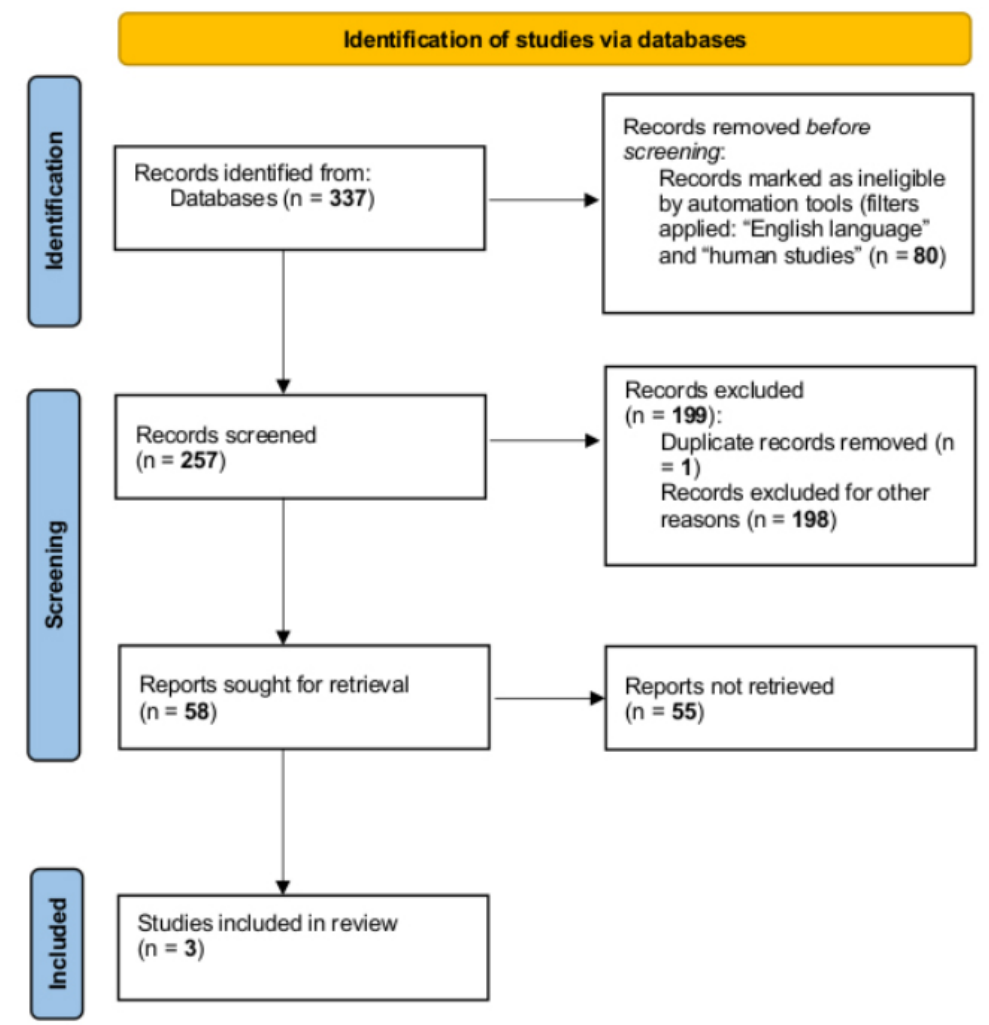

Second search, performed on databases MEDLINE and EMBASE until May 20, 2021, using the terms "androgen replacement

therapy", "testosterone", "male hypogonadism", "prediabetes", "IFG", "impaired fasting glucose", "IGT", "impaired glucose tolerance".

Figure 3. Flow chart of the second literature search.

in these patients.

Overall, a bidirectional association between male hypogonadism and pre-diabetes has been identified ${ }^{[72,73]}$. Similarly to what happens for other chronic diseases ${ }^{[3]}$, recommendation statements ${ }^{[7]}$ and guidelines ${ }^{[16]}$ on male hypogonadism management recognize $\mathrm{T} 2 \mathrm{DM}$ as one of the main determinants of $\mathrm{T}$ decline. Our systematic review suggests that pre-diabetes should also be considered among risk factors of $\mathrm{T}$ reduction and male hypogonadism development. Consistently with this hypothesis, the mildest forms of glucose impairment are associated with a reduced sexual response ${ }^{[75]}$, resulting in erectile dysfunction ${ }^{[12]}$ and confirming that glucose homeostasis dysregulation could influence many aspect of male hypogonadism ${ }^{[76]}$. While a stepwise $\mathrm{T}$ decrease as a function of glucose abnormalities was strongly suggested ${ }^{[1,62,63]}$, the change in SHBG serum levels occurring in DM and pre-diabetes is still debated. Particularly, the association of T2DM with the metabolic impairment of liver function can interfere with SHBG levels. However, it is not clear whether pre-diabetes results in SHBG reduction ${ }^{[12,40,58,63]}$ or not ${ }^{[40,46,56,62]}$. Thus, despite the association between reduced total $\mathrm{T}$ serum levels and pre-diabetes, there is no clear evidence of a reduction in bioavailable T. Similarly, estradiol serum levels were described to be reduced ${ }^{[46,5,58,3}$ or not $^{[40,57,61,62]}$ in prediabetic patients, leaving doubts about the clinical consequences of the reduction of total $\mathrm{T}$ serum levels in pre-diabetes.

The mechanistic, molecular link between pre-diabetes and male hypogonadism is still undefined. Animal models showed that mild hyperglycemia and glucose intolerance are associated with hypertension, 
Table 3. Characteristics of studies considered in the second literature search: effects of androgen-replacement therapy on glucose metabolism in pre-diabetic males. Data are expressed as mean 4 standard deviation

\begin{tabular}{|c|c|c|c|c|c|c|c|c|c|c|c|c|c|c|}
\hline \multirow[b]{2}{*}{ Authors, year } & \multirow[b]{2}{*}{ Aim of the study } & \multirow[b]{2}{*}{$\begin{array}{l}\text { Diagnostic } \\
\text { criteria }\end{array}$} & \multicolumn{6}{|c|}{ Study group } & \multicolumn{6}{|c|}{ Control group } \\
\hline & & & Treatment & Subjects & $\begin{array}{l}\text { Age } \\
\text { (years) }\end{array}$ & $\begin{array}{l}\mathrm{BMI} \\
\left(\mathrm{kg} / \mathrm{m}^{2}\right)\end{array}$ & $\begin{array}{l}\text { Baseline } \\
2 \mathrm{~h} \\
\text { OGTT } \\
(\mathrm{mg} / \mathrm{dL})\end{array}$ & $\begin{array}{l}\text { 2-OGTT } \\
\text { after } \\
\text { treatment } \\
(\mathrm{mg} / \mathrm{dL})\end{array}$ & Treatment & Subjects & $\begin{array}{l}\text { Age } \\
\text { (years) }\end{array}$ & $\begin{array}{l}\mathrm{BMI} \\
\left(\mathrm{kg} / \mathrm{m}^{2}\right)\end{array}$ & $\begin{array}{l}\text { Baseline } \\
2 \text { h } \\
\text { OGTT } \\
(\mathrm{mg} / \mathrm{dL})\end{array}$ & $\begin{array}{l}2 \text { h OGTT } \\
\text { after } \\
\text { treatment } \\
(\mathrm{mg} / \mathrm{dL})\end{array}$ \\
\hline $\begin{array}{l}\text { Krysiak et al. }{ }^{[68]} \text {, } \\
2015\end{array}$ & $\begin{array}{l}\text { To investigate the } \\
\text { effect of metformin, } \\
\text { alone or with } \\
\text { testosterone, on } \\
\text { cardiometabolic } \\
\text { risk factors in } \\
\text { hypogonadal men }\end{array}$ & $\begin{array}{l}\text { Hypogonadism } \\
\text { TT< } 10.4 \\
\text { nmol/L } \\
\text { Pre-diabetes } \\
\text { FPG: }<100 \\
\text { mg/dL } \\
2 \mathrm{~h} \mathrm{OGTT} 140- \\
199 \text { mg/dL }\end{array}$ & $\begin{array}{l}\text { Oral } \\
\text { testosterone } \\
\text { undecanoate } \\
\text { (120 mg daily) } \\
+ \text { metformin } \\
(1.7 \mathrm{~g} \text { daily) } \\
\text { for } 24 \text { weeks }\end{array}$ & 14 & $65 \pm 4$ & $29.2 \pm 3.2$ & $182 \pm 10$ & $145 \pm 12$ & $\begin{array}{l}\text { Metformin } \\
\text { (1.7g daily) } \\
\text { for } 24 \text { weeks }\end{array}$ & 14 & $64 \pm 5$ & $29 \pm 3$ & $178 \pm 11$ & $153 \pm 14$ \\
\hline $\begin{array}{l}\text { Yassin et al. }{ }^{[69]}, \\
2019\end{array}$ & $\begin{array}{l}\text { To investigate } \\
\text { whether } \\
\text { testosterone } \\
\text { therapy in men with } \\
\text { hypogonadism and } \\
\text { pre-diabetes } \\
\text { prevents } \\
\text { progression to } \\
\text { T2DM }\end{array}$ & $\begin{array}{l}\text { Hypogonadism } \\
\text { TT } \leq 12.1 \\
\text { nmol/L } \\
\text { Pre-diabetes } \\
\mathrm{HbA1c} 39-46 \\
\mathrm{mmol} / \mathrm{mol}\end{array}$ & $\begin{array}{l}\text { Parenteral } \\
\text { testosterone } \\
\text { undecanoate } \\
(1000 \mathrm{mg} \\
\text { every } 12 \\
\text { weeks) for } \\
\text { eight years }\end{array}$ & 229 & $\begin{array}{l}58.2 \pm \\
9.6\end{array}$ & $30.7 \pm 4.1$ & $41 \pm 6.1$ & NA & $\begin{array}{l}\text { No } \\
\text { treatment }\end{array}$ & 83 & $\begin{array}{l}66.4 \pm \\
7.2\end{array}$ & $29.8 \pm 3$ & $41 \pm 7.2$ & NA \\
\hline $\begin{array}{l}\text { Strollo et al }{ }^{[70]} \text {, } \\
2013\end{array}$ & $\begin{array}{l}\text { To verify whether } \\
\text { oral, buccal, and } \\
\text { transdermal TRT } \\
\text { administered at a } \\
\text { dosage lower than } \\
\text { that commonly } \\
\text { utilized in young } \\
\text { hypogonadal men } \\
\text { improves frailty } \\
\text { symptoms in } \\
\text { elderly men with } \\
\text { visceral adiposity, } \\
\text { IFG, and LOH }\end{array}$ & $\begin{array}{l}\text { Hypogonadism } \\
\mathrm{TT}<8 \mathrm{nmol} / \mathrm{L} \\
\text { Pre-diabetes } \\
\mathrm{FPG}>100 \\
\mathrm{mg} / \mathrm{dL}\end{array}$ & $\begin{array}{l}\text { (a) Oral } \\
\text { testosterone } \\
\text { undecanoate } \\
80 \text { mg daily } \\
\text { (b) Buccal } \\
\text { testosterone } \\
60 \text { mg daily } \\
\text { (c) } \\
\text { Transdermal } \\
\text { testosterone } \\
30 \text { mg daily }\end{array}$ & $\begin{array}{l}\text { (a) } 15 \\
\text { (b) } 18 \\
\text { (c) } 15 \\
\text { (all 48) }\end{array}$ & $\begin{array}{l}\text { (a) } 70.0 \\
\pm 3.1 \\
\text { (b) } 69.3 \\
\pm 3.0 \\
\text { (c) } 70.1 \\
\pm 2.9\end{array}$ & $\begin{array}{l}\text { (a) } 27.7 \pm 1.3 \\
\text { (b) } 29.4 \pm 2.4 \\
\text { (c) } 28.6 \pm 2.0\end{array}$ & $\begin{array}{l}\text { (a) } 108 \pm \\
5 \\
\text { (b) } 111 \pm 5 \\
\text { (c) } 110 \pm 6\end{array}$ & $\begin{array}{l}\text { (a) } 101 \pm 6 \\
\text { (b) } 103 \pm 8 \\
\text { (c) } 100 \pm 9\end{array}$ & $\begin{array}{l}\text { No } \\
\text { treatment }\end{array}$ & 16 & $\begin{array}{l}68.5 \pm \\
3.7\end{array}$ & $28.4 \pm 1.9$ & $109 \pm 6$ & $107 \pm 8$ \\
\hline
\end{tabular}

BMI: Body mass index; IFG: impaired fasting glucose; FPG: fasting plasma glucose; OGTT: oral glucose tolerance test; LOH: late onset hypogonadism; NA: not available; T2DM: type 2 diabetes mellitus; TRT: testosterone replacement therapy; TT: total testosterone. 


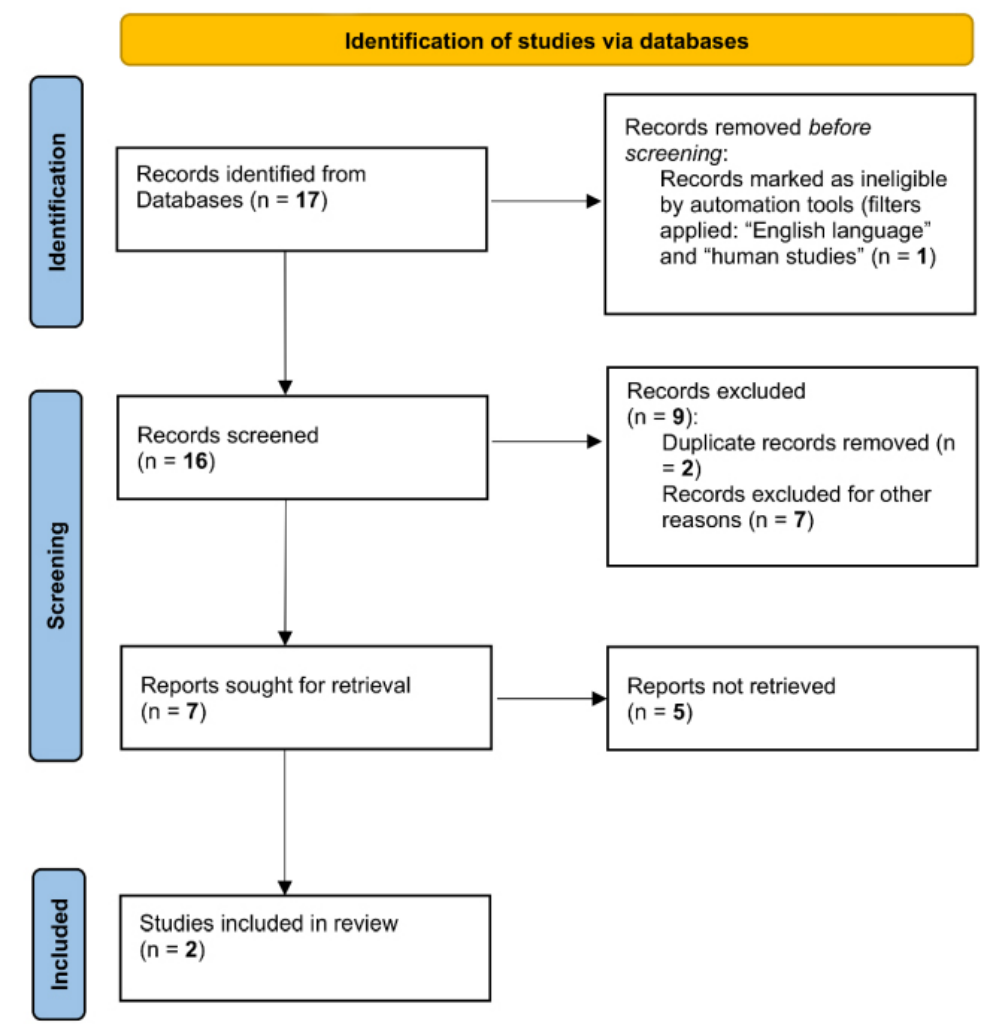

Third search, performed on databases MEDLINE and EMBASE until May 20, 2021, using the terms "lifestyle", "antidiabetic drugs",

"metformin", "male hypogonadism", "prediabetes", "IFG", "impaired fasting glucose", "IGT", "impaired glucose tolerance".

Figure 4. Flow chart of the third literature search.

increased visceral adiposity, and a reduced number of gonadotropin-releasing hormone (GnRH) neurons in the hypothalamus of the pre-diabetic rabbit ${ }^{[77]}$. In this model, pre-diabetic conditions created by a longterm, high-fat diet could induce a hypogonadotropic hypogonadism comparable to that obtained with a long-acting $\mathrm{GnRH}$ analog ${ }^{[77]}$. Similarly, impaired insulin secretion could induce a hypogonadotropic hypogonadism in other animal models ${ }^{[78-80]}$, suggesting that either glucose homeostasis impairment or the lack of insulin signaling within the brain could be the pathogenic mechanism connecting hypogonadism and diabetes. Moreover, increased body fat and adiposity have been considered the hidden link between glucose homeostasis impairment and low total $\mathrm{T}$ serum level ${ }^{[42]}$. Indeed, total and bioavailable $\mathrm{T}$ levels in men were inversely associated with total body fat ${ }^{[81,82]}$. This suggestion was confirmed even after statistical adjusting for BMI, which reduces but does not eliminate the T-diabetes associations ${ }^{[61]}$. Moreover, serum $\mathrm{T}$ levels are inversely related to BMI in obese men, and androgen administration increases insulin sensitivity ${ }^{[83,84]}$. Accordingly, insulin resistance decreases after T replacement in T2DM patients ${ }^{[85,86]}$. This Trelated effect on insulin sensitivity is probably multifactorial ${ }^{[42]}$. Our systematic review is not able to clarify the cause-effect relationship between $\mathrm{T}$ and glucose metabolism, but it clearly confirms this potential association.

Limited evidence is available considering male hypogonadism. Indeed, only two studies evaluated the association between total $\mathrm{T}$ serum levels and pre-diabetes enrolling hypogonadal $\operatorname{men}^{[37,67]}$. Hypogonadal men show a higher degree of insulin resistance and pre-diabetes compared to eugonadal men. This result 
Table 4. Characteristics of studies considered in the third literature search: effects of anti-diabetic treatment on male hypogonadism. Data are expressed as mean 4 standard deviation

\begin{tabular}{|c|c|c|c|c|c|c|c|c|c|c|c|c|c|}
\hline \multirow[b]{2}{*}{ Authors, year } & \multirow[b]{2}{*}{ Aim of the study } & \multirow[b]{2}{*}{ Diagnostic Criteria } & \multirow[b]{2}{*}{ Treatment } & \multicolumn{5}{|c|}{ Study group } & \multicolumn{5}{|c|}{ Control group } \\
\hline & & & & Subjects & $\begin{array}{l}\text { Age } \\
\text { (years) }\end{array}$ & $\underset{\left(\mathrm{kg} / \mathrm{m}^{2}\right)}{\mathrm{BMI}}$ & $\begin{array}{l}\text { Baseline } \\
\text { TT } \\
\text { (nmol/L) }\end{array}$ & $\begin{array}{l}\text { TT after } \\
\text { treatment } \\
\text { (nmol/L) }\end{array}$ & Subjects & $\begin{array}{l}\text { Age } \\
\text { (years) }\end{array}$ & $\underset{\left(\mathrm{kg} / \mathrm{m}^{2}\right)}{\mathrm{BMI}}$ & $\begin{array}{l}\text { Baseline } \\
\text { TT } \\
(\mathrm{nmol} / \mathrm{L})\end{array}$ & $\begin{array}{l}\text { TT after } \\
\text { treatment } \\
\text { (nmol/L) }\end{array}$ \\
\hline $\begin{array}{l}\text { Krysiak et al. }{ }^{[71]} \text {, } \\
2021\end{array}$ & $\begin{array}{l}\text { To investigate } \\
\text { hypothalamic-pituitary- } \\
\text { testicular axis activity in } \\
\text { men with primary } \\
\text { hypogonadism receiving } \\
\text { metformin }\end{array}$ & $\begin{array}{l}\text { Hypogonadism } \\
\text { TT < } 8.7 \text { nmol/L } \\
\text { Pre-diabetes } \\
\text { FPG: } 100-125 \mathrm{mg} / \mathrm{dL} \\
2 \mathrm{~h} \text { OGTT } 140-199 \\
\mathrm{mg} / \mathrm{dL}\end{array}$ & $\begin{array}{l}\text { Metformin } \\
2.55-3 \mathrm{~g} \text { daily } \\
\text { for } 16 \text { weeks }\end{array}$ & 10 & $43 \pm 8$ & $28.1 \pm 5.2$ & $5.6 \pm 3$ & $5.7 \pm 3.3$ & 19 & $44 \pm 7$ & $27.6 \pm 4.2$ & $20.3 \pm 8.7$ & $21 \pm 9.8$ \\
\hline $\begin{array}{l}\text { Krysiak et al. }{ }^{[68]} \text {, } \\
2015\end{array}$ & $\begin{array}{l}\text { To investigate the effect } \\
\text { of metformin, alone or } \\
\text { with testosterone, on } \\
\text { cardiometabolic risk } \\
\text { factors in hypogonadal } \\
\text { men }\end{array}$ & $\begin{array}{l}\text { Hypogonadism TT }< \\
10.4 \text { mol/L } \\
\text { Pre-diabetes } \\
2 \text { h OGTT 140-199 } \\
\mathrm{mg} / \mathrm{dL}\end{array}$ & $\begin{array}{l}\text { Metformin } 1.7 \\
\text { g daily for } 24 \\
\text { weeks }\end{array}$ & 14 & $64 \pm 5$ & $29 \pm 3.0$ & $6.2 \pm 1.0$ & $7.3 \pm 1.7$ & 12 & $67 \pm 4$ & $28.7 \pm 3.4$ & NA & NA \\
\hline
\end{tabular}

BMI: Body mass index; FPG: fasting plasma glucose; OGTT: oral glucose tolerance test; NA: not available; TT: total testosterone.

indicates that low total $\mathrm{T}$ serum level is an independent risk factor of pre-diabetes, which most likely affects glucose tolerance during OGTT more than fasting plasma glucose concentrations ${ }^{[67]}$. Although these studies clearly demonstrate an indirect correlation between total T serum levels and glycemic control in hypogonadal men, the amount of evidence limits the robustness of this association. Similarly, the pathophysiological mechanisms causing pre-diabetes in $\mathrm{T}$ deficiency are still unknown.

Considering the treatment, it has been suggested that $\mathrm{T}$ administration in pre-diabetic hypogonadal men could prevent the pre-diabetes progression to overt $\mathrm{T} 2 \mathrm{DM}$, as suggested by the reduction in $\mathrm{HbA}_{1} \mathrm{c}^{[6]}$ or insulin resistance ${ }^{[5]}$. The result of our systematic review, although limited for the low number of studies included, could be extremely useful in clinical practice. Indeed, the literature suggests that pre-diabetic hypogonadal men would develop T2DM in more than $40 \%$ of cases ${ }^{[69]}$. Thus, the clinical management of both conditions could be useful to slow down disease development and onset of complications. In particular, although the association between pre-diabetes and cardiovascular mortality risks is clearly demonstrated ${ }^{[87]}$, high-quality studies are required to evaluate whether $\mathrm{T}$ administration could reduce this risk. According to our review, combined $\mathrm{T}$ and metformin administration may be useful in the management of men with hypogonadism coexisting with early glucose metabolism abnormalities. Indeed, while metformin improves glucose metabolism, the euglycemic state could be more efficiently obtained by $\mathrm{T}$ replacement ${ }^{[5]}$. Therefore, the question arises whether $\mathrm{T}$ treatment should be given to all patients with pre-diabetes and hypogonadism in order to prevent development into overt T2DM. The evidence currently available is still insufficient and future studies should be dedicated to this topic. 
Similarly, speculatively, no clear conclusion could be drawn on the efficacy of anti-diabetic drugs in improving sex hormone status in pre-diabetic hypogonadal men. Indeed, this association has been even less and only superficially studied. Several studies suggested that weight loss improves $\mathrm{T}$ in obese T2DM men, more than glycemic control ${ }^{[88]}$. However, less information is available in pre-diabetic men, and only two studies evaluated the effect of metformin on T levels. Moreover, no studies evaluated the combined androgen and anti-diabetic approaches in this setting. In the studies available, chronic metformin administration did not improve serum $\mathrm{T}$ levels, leaving the field open for debate. In general, we can conclude that $\mathrm{T}$ administration reduces the $\mathrm{T} 2 \mathrm{DM}$ risk beyond lifestyle intervention alone ${ }^{[88]}$.

\section{Clinical implications}

Men with documented total $\mathrm{T}$ serum levels below $8 \mathrm{nmol} / \mathrm{L}$ or below $12.1 \mathrm{nmol} / \mathrm{L}$ with signs or symptoms related to hypogonadism ${ }^{[16]}$ should be treated with exogenous $\mathrm{T}$ administration ${ }^{[18]}$. The treatment should be tailored to patient's health status, expectations, and potential adverse event ${ }^{[15]}$. T replacement therapy is surely effective in improving sexual function, body composition, and metabolic outcomes ${ }^{[44]}$. On the contrary, pre-diabetes-related treatments should be reserved aiming to control glucose metabolism, since the evidence of a positive effect on total $\mathrm{T}$ serum levels is not available yet. Therefore, $\mathrm{T}$ replacement therapy should not be considered a potential therapy to treat pre-diabetes, but positive effects on glucose metabolism may be expected in T-treated patients with male hypogonadism.

Conversely, the treatment of pre-diabetes status in men with hypogonadism may indirectly have positive effects on serum $\mathrm{T}$ levels since lifestyle changes (both dietary changes and increasing physical activity) are able to improve serum $\mathrm{T}$ levels ${ }^{[8-91]}$.

\section{Unresolved issues}

Glucose metabolism disorders are an established risk factor for $\mathrm{T}$ decline in men. However, the influence of pre-diabetes on $\mathrm{T}$ deficiency is still not completely known. In particular, the first unresolved issue remains the exact moment of total T decline in the natural history of T2DM. Prospective studies are needed to determine the cause-effect relationship of sex hormone-glucose metabolism association and the timing of the onset of a condition in the presence of the other one. Clinically, it is important to establish exactly whether pre-diabetes can be considered as an early sign of male hypogonadism. Here, we describe a male hypogonadism prevalence ranging from $24 \%$ to $35 \%$ in pre-diabetic men, suggesting that detailed glucose metabolism investigation should be performed in every man with biochemical and/or symptomatic hypogonadism. The second main issue remains whether to implement a prevention program to reduce progression to $\mathrm{T} 2 \mathrm{DM}$ in such men.

The third unresolved issue is the knowledge of the possible pathophysiological mechanism effecting prediabetes and $\mathrm{T}$ decline. This association is probably multifactorial and represented mainly by visceral adiposity and insulin resistance. However, concerning the hypothalamic function, the pathogenic role of the impairment of glucose homeostasis and insulin signaling directly in the brain and $\mathrm{GnRH}$ neurons remains to be clarified. The fourth unresolved issue is the accurate characterization of hypogonadism in pre-diabetic males. Indeed, it is not completely clear if the total $\mathrm{T}$ decline results in a decrease of bioavailable $\mathrm{T}$. Future research should focus on the SHBG and estradiol changes in pre-diabetes. Moreover, the sex hormone measurement must be performed by the gold-standard technique, i.e., mass spectrometry ${ }^{[2,93]}$. Finally, the studies considered here were limited to biochemical hypogonadism, without information about gonadotropin serum levels. Thus, this analysis is unable to describe the pathomechanism (primary/secondary hypogonadism) and to distinguish whether the hypo- or hyper-gonadotropic form of hypogonadism would be the best responder to treatments. Similarly, no information about the severity of hypogonadism and its correlation with glucose metabolism alterations is available. Finally, future research 
should be oriented to study the role of new anti-diabetic drugs (such as glucagon-like peptide-1 receptor agonists and sodium-glucose cotransporter-2 inhibitors) in the sex hormonal status in hypogonadal men.

\section{DECLARATIONS}

\section{Authors' contributions}

Conceive the study: Greco C, Santi D

Extracted data: Greco C, Corleto R, Ebert R, Santi D

Revised the manuscript: Simoni M, Rochira V

\section{Availability of data and materials}

Not applicable.

\section{Financial support and sponsorship}

None.

\section{Conflicts of interest}

All authors declared that there are no conflicts of interest.

\section{Ethical approval and consent to participate}

Not applicable.

\section{Consent for publication}

Not applicable.

\section{Copyright}

(c) The Author(s) 2021.

\section{REFERENCES}

1. Bebb R, Millar A, Brock G; Diabetes Canada Clinical Practice Guidelines Expert Committee. Sexual dysfunction and hypogonadism in men with diabetes. Can J Diabetes 2018;42 Suppl 1:S228-33. DOI PubMed

2. Dhindsa S, Ghanim H, Batra M, Dandona P. Hypogonadotropic hypogonadism in men with diabesity. Diabetes Care 2018;41:151625. DOI PubMed PMC

3. Rochira V. Hypogonadism in systemic diseases. In: Simoni M, Huhtaniemi I, editors. Endocrinology of the testis and male reproduction. Cham: Springer International Publishing; 2017. p. 1-51. DOI

4. Ding EL, Song Y, Malik VS, Liu S. Sex differences of endogenous sex hormones and risk of type 2 diabetes: a systematic review and meta-analysis. JAMA 2006;295:1288-99. DOI PubMed

5. Atlantis E, Fahey P, Martin S, et al. Predictive value of serum testosterone for type 2 diabetes risk assessment in men. BMC Endocr Disord 2016;16:26. DOI PubMed PMC

6. Diabetes Association. 2. Classification and diagnosis of diabetes: standards of medical care in diabetes-2021. Diabetes Care 2021;44:S15-33. DOI PubMed

7. World Health Organization. Definition and diagnosis of diabetes mellitus and intermediate hyperglycaemia: report of a WHO/IDF consultation. Available from: https://apps.who.int/iris/bitstream/handle/10665/43588/9241594934_eng.pdf [Last accessed on 29 Nov 2021].

8. Tabák AG, Herder C, Rathmann W, Brunner EJ, Kivimäki M. Prediabetes: a high-risk state for diabetes development. Lancet 2012;379:2279-90. DOI PubMed PMC

9. Alvarez S, Coffey R, Algotar AM. Prediabetes. In: StatPearls [Internet]. Treasure Island (FL): StatPearls Publishing; 2021. PubMed

10. Sörensen BM, Houben AJ, Berendschot TT, et al. Prediabetes and type 2 diabetes are associated with generalized microvascular dysfunction: the maastricht study. Circulation 2016;134:1339-52. DOI PubMed

11. Ford ES, Zhao G, Li C. Pre-diabetes and the risk for cardiovascular disease: a systematic review of the evidence. J Am Coll Cardiol 2010;55:1310-7. DOI PubMed

12. Corona G, Rastrelli G, Balercia G, et al. Hormonal association and sexual dysfunction in patients with impaired fasting glucose: a cross-sectional and longitudinal study. J Sex Med 2012;9:1669-80. DOI PubMed

13. Buysschaert M, Medina JL, Bergman M, Shah A, Lonier J. Prediabetes and associated disorders. Endocrine 2015;48:371-93. DOI PubMed 
14. Greco C, Spallone V. Obstructive sleep apnoea syndrome and diabetes. Fortuitous association or interaction? Curr Diabetes Rev 2015;12:129-55. DOI PubMed

15. Decaroli MC, Rochira V. Aging and sex hormones in males. Virulence 2017;8:545-70. DOI PubMed PMC

16. Wu FC, Tajar A, Beynon JM, et al; EMAS Group. Identification of late-onset hypogonadism in middle-aged and elderly men. $N$ Engl $J$ Med 2010;363:123-35. DOI PubMed

17. Basaria S. Male hypogonadism. Lancet 2014;383:1250-63. DOI PubMed

18. Bhasin S, Brito JP, Cunningham GR, et al. Testosterone therapy in men with hypogonadism: an endocrine society clinical practice guideline. J Clin Endocrinol Metab 2018;103:1715-44. DOI PubMed

19. Swiecicka A, Wu F. Clinical manifestation and diagnosis of androgen deficiency. In: Simoni M, Huhtaniemi I, Editors. Endocrinology of the testis and male reproduction. Cham: Springer International Publishing; 2017. p. 1-18.

20. Dean JD, McMahon CG, Guay AT, et al. The international society for sexual medicine's process of care for the assessment and management of testosterone deficiency in adult men. J Sex Med 2015;12:1660-86. DOI PubMed

21. Hackett G, Kirby M, Edwards D, et al. British society for sexual medicine guidelines on adult testosterone deficiency, with statements for UK practice. $J$ Sex Med 2017;14:1504-23. DOI PubMed

22. Wang C, Nieschlag E, Swerdloff R, et al; International Society of Andrology (ISA), International Society for the Study of Aging Male (ISSAM), European Association of Urology (EAU), European Academy of Andrology (EAA), American Society of Andrology (ASA). Investigation, treatment, and monitoring of late-onset hypogonadism in males: ISA, ISSAM, EAU, EAA, and ASA recommendations. J Androl 2009;30:1-9. DOI PubMed

23. Salonia A, Bettocchi C, Boeri L, et al; EAU Working Group on Male Sexual and Reproductive Health. European Association of urology guidelines on sexual and reproductive health-2021 update: male sexual dysfunction. Eur Urol 2021;80:333-57. DOI PubMed

24. Bhasin S, Pencina M, Jasuja GK, et al. Reference ranges for testosterone in men generated using liquid chromatography tandem mass spectrometry in a community-based sample of healthy nonobese young men in the Framingham Heart Study and applied to three geographically distinct cohorts. J Clin Endocrinol Metab 2011;96:2430-9. DOI PubMed PMC

25. Huhtaniemi IT, Tajar A, Lee DM, et al; EMAS Group. Comparison of serum testosterone and estradiol measurements in 3174 European men using platform immunoassay and mass spectrometry; relevance for the diagnostics in aging men. Eur J Endocrinol 2012;166:983-91. DOI PubMed

26. Frost M, Wraae K, Nielsen TL, et al. Similar reference intervals for total testosterone in healthy young and elderly men: results from the Odense Androgen Study. Clin Endocrinol (Oxf) 2013;78:743-51. DOI PubMed

27. Sartorius G, Spasevska S, Idan A, et al. Serum testosterone, dihydrotestosterone and estradiol concentrations in older men selfreporting very good health: the healthy man study. Clin Endocrinol (Oxf) 2012;77:755-63. DOI PubMed

28. Grossmann M, Jones TH. Functional hypogonadism in middle-aged and older men: testosterone treatment or not? Eur J Endocrinol 2021;185:D1-9. DOI PubMed

29. Gyawali P, Martin SA, Heilbronn LK, et al. The role of sex hormone-binding globulin (SHBG), testosterone, and other sex steroids, on the development of type 2 diabetes in a cohort of community-dwelling middle-aged to elderly men. Acta Diabetol 2018;55:861-72. DOI PubMed

30. Hu J, Zhang A, Yang S, et al. Combined effects of sex hormone-binding globulin and sex hormones on risk of incident type 2 diabetes. $J$ Diabetes 2016;8:508-15. DOI PubMed

31. Yao QM, Wang B, An XF, Zhang JA, Ding L. Testosterone level and risk of type 2 diabetes in men: a systematic review and metaanalysis. Endocr Connect 2018;7:220-31. DOI PubMed PMC

32. Malipatil NS, Yadegarfar G, Lunt M, et al. Male hypogonadism: 14-year prospective outcome in 550 men with type 2 diabetes. Endocrinol Diabetes Metab 2019;2:e00064. DOI PubMed PMC

33. Zhang J, Li X, Cai Z, Li H, Yang B. Association between testosterone with type 2 diabetes in adult males, a meta-analysis and trial sequential analysis. Aging Male 2020;23:607-18. DOI PubMed

34. Simon D, Preziosi P, Barrett-Connor E, et al. Interrelation between plasma testosterone and plasma insulin in healthy adult men: the Telecom Study. Diabetologia 1992;35:173-7. DOI PubMed

35. Pitteloud N, Hardin M, Dwyer AA, et al. Increasing insulin resistance is associated with a decrease in Leydig cell testosterone secretion in men. J Clin Endocrinol Metab 2005;90:2636-41. DOI PubMed

36. Contreras PH, Serrano FG, Salgado AM, Vigil P. Insulin sensitivity and testicular function in a cohort of adult males suspected of being insulin-resistant. Front Med (Lausanne) 2018;5:190. DOI PubMed PMC

37. Pitteloud N, Mootha VK, Dwyer AA, et al. Relationship between testosterone levels, insulin sensitivity, and mitochondrial function in men. Diabetes Care 2005;28:1636-42. DOI PubMed

38. Grossmann M, Thomas MC, Panagiotopoulos S, et al. Low testosterone levels are common and associated with insulin resistance in men with diabetes. J Clin Endocrinol Metab 2008;93:1834-40. DOI PubMed

39. Souteiro P, Belo S, Oliveira SC, et al; AMTCO Group. Insulin resistance and sex hormone-binding globulin are independently correlated with low free testosterone levels in obese males. Andrologia 2018;50:e13035. DOI PubMed

40. Arthur R, Rohrmann S, Møller H, et al. Pre-diabetes and serum sex steroid hormones among US men. Andrology 2017;5:49-57. DOI PubMed

41. Oh JY, Barrett-Connor E, Wedick NM, Wingard DL; Rancho Bernardo Study. Endogenous sex hormones and the development of type 2 diabetes in older men and women: the Rancho Bernardo study. Diabetes Care 2002;25:55-60. DOI PubMed

42. Dandona P, Dhindsa S, Ghanim H, Saad F. Mechanisms underlying the metabolic actions of testosterone in humans: a narrative review. Diabetes Obes Metab 2021;23:18-28. DOI PubMed 
43. Corona G, Giagulli VA, Maseroli E, et al. Testosterone supplementation and body composition: results from a meta-analysis of observational studies. J Endocrinol Invest 2016;39:967-81. DOI PubMed

44. Corona G, Giagulli VA, Maseroli E, et al. Therapy of endocrine disease: testosterone supplementation and body composition: results from a meta-analysis study. Eur J Endocrinol 2016;174:R99-116. DOI PubMed

45. Isidori AM, Giannetta E, Greco EA, et al. Effects of testosterone on body composition, bone metabolism and serum lipid profile in middle-aged men: a meta-analysis. Clin Endocrinol (Oxf) 2005;63:280-93. DOI PubMed

46. Rabijewski M, Papierska L, Piątkiewicz P. The relationships between anabolic hormones and body composition in middle-aged and elderly men with prediabetes: a cross-sectional study. J Diabetes Res 2016;2016:1747261. DOI PubMed PMC

47. Caliber M, Saad F. Testosterone therapy for prevention and reversal of type 2 diabetes in men with low testosterone. Curr Opin Pharmacol 2021;58:83-9. DOI PubMed

48. Wittert G, Bracken K, Robledo KP, et al. Testosterone treatment to prevent or revert type 2 diabetes in men enrolled in a lifestyle programme (T4DM): a randomised, double-blind, placebo-controlled, 2-year, phase 3b trial. Lancet Diabetes Endocrinol 2021;9:3245. DOI PubMed

49. Haider KS, Haider A, Saad F, et al. Remission of type 2 diabetes following long-term treatment with injectable testosterone undecanoate in patients with hypogonadism and type 2 diabetes: 11-year data from a real-world registry study. Diabetes Obes Metab 2020;22:2055-68. DOI PubMed PMC

50. Mårin P, Odén B, Björntorp P. Assimilation and mobilization of triglycerides in subcutaneous abdominal and femoral adipose tissue in vivo in men: effects of androgens. J Clin Endocrinol Metab 1995;80:239-43. DOI PubMed

51. Singh R, Artaza JN, Taylor WE, et al. Testosterone inhibits adipogenic differentiation in 3T3-L1 cells: nuclear translocation of androgen receptor complex with beta-catenin and T-cell factor 4 may bypass canonical Wnt signaling to down-regulate adipogenic transcription factors. Endocrinology 2006;147:141-54. DOI PubMed PMC

52. Singh R, Artaza JN, Taylor WE, Gonzalez-Cadavid NF, Bhasin S. Androgens stimulate myogenic differentiation and inhibit adipogenesis in C3H 10T1/2 pluripotent cells through an androgen receptor-mediated pathway. Endocrinology 2003;144:5081-8. DOI PubMed

53. Dyson PA. The therapeutics of lifestyle management on obesity. Diabetes Obes Metab 2010;12:941-6. DOI PubMed

54. Benvenuti S, Cellai I, Luciani P, et al. Androgens and estrogens prevent rosiglitazone-induced adipogenesis in human mesenchymal stem cells. J Endocrinol Invest 2012;35:365-71. DOI PubMed

55. Abdelzaher WY, Rofaeil RR, Ali DME, Attya ME. Protective effect of dipeptidyl peptidase-4 inhibitors in testicular torsion/detorsion in rats: a possible role of HIF-1 $\alpha$ and nitric oxide. Naunyn Schmiedebergs Arch Pharmacol 2020;393:603-14. DOI PubMed

56. Rabijewski M, Papierska L, Piątkiewicz P. Late-onset hypogonadism among old and middle-aged males with prediabetes in Polish population. Aging Male 2015;18:16-21. DOI PubMed

57. Boeri L, Capogrosso P, Pederzoli F, et al. Unrecognized prediabetes is highly prevalent in men with erectile dysfunction-results from a cross-sectional study. J Sex Med 2018;15:1117-24. DOI PubMed

58. Boeri L, Capogrosso P, Ventimiglia E, et al. Undiagnosed prediabetes is highly prevalent in primary infertile men - results from a cross-sectional study. BJU Int 2019;123:1070-7. DOI PubMed

59. Ho CH, Yu HJ, Wang CY, et al. Prediabetes is associated with an increased risk of testosterone deficiency, independent of obesity and metabolic syndrome. PLoS One 2013;8:e74173. DOI PubMed PMC

60. Zhu H, Wang N, Han B, et al. Low Sex Hormone-binding globulin levels associate with prediabetes in chinese men independent of total testosterone. PLoS One 2016;11:e0162004. DOI PubMed PMC

61. Goodman-Gruen D, Barrett-Connor E. Sex differences in the association of endogenous sex hormone levels and glucose tolerance status in older men and women. Diabetes Care 2000;23:912-8. DOI PubMed

62. Lu Y, Li J, Cheng X, et al. Testosterone level in aging male with different glucose tolerance state and its association with osteocalcin. Aging Male 2019;22:68-73. DOI PubMed

63. Colangelo LA, Ouyang P, Liu K, et al. Association of endogenous sex hormones with diabetes and impaired fasting glucose in men: multi-ethnic study of atherosclerosis. Diabetes Care 2009;32:1049-51. DOI PubMed PMC

64. Liu X, Jiang J, Liu X, et al. Association of serum testosterone with different classes of glucose metabolism and the mediation effect of obesity: the henan rural cohort study. Diabetes Metab Res Rev 2019;35:e3133. DOI PubMed

65. Chen X, Wu Y, Liu L, Tian H, Yu X. Osteocalcin is inversely associated with glucose levels in middle-aged Tibetan men with different degrees of glucose tolerance. Diabetes Metab Res Rev 2014;30:476-82. DOI PubMed

66. Minooee S, Ramezani Tehrani F, Rahmati M, et al. The association between serum total testosterone and progression of hyperglycemia: a 15-year prospective cohort study. Andrology 2019;7:148-55. DOI PubMed

67. Rabijewski M, Papierska L, Piątkiewicz P. The prevalence of prediabetes in population of Polish men with late-onset hypogonadism. Aging Male 2014;17:141-6. DOI PubMed

68. Krysiak R, Gilowski W, Okopien B. The effect of metformin and metformin-testosterone combination on cardiometabolic risk factors in men with late-onset hypogonadism and impaired glucose tolerance. Exp Clin Endocrinol Diabetes 2015;123:608-13. DOI PubMed

69. Yassin A, Haider A, Haider KS, et al. Testosterone therapy in men with hypogonadism prevents progression from prediabetes to type 2 diabetes: eight-year data from a registry study. Diabetes Care 2019;42:1104-11. DOI PubMed

70. Strollo F, Strollo G, Morè M, et al. Low-intermediate dose testosterone replacement therapy by different pharmaceutical preparations improves frailty score in elderly hypogonadal hyperglycaemic patients. Aging Male 2013;16:33-7. DOI PubMed

71. Krysiak R, Szkróbka W, Bednarska-Czerwińska A, Okopień B. Plasma gonadotropin levels in metformin-treated men with prediabetes: a non-randomized, uncontrolled pilot study. Fundam Clin Pharmacol 2021;35:466-72. DOI PubMed 
72. Stellato RK, Feldman HA, Hamdy O, Horton ES, McKinlay JB. Testosterone, sex hormone-binding globulin, and the development of type 2 diabetes in middle-aged men: prospective results from the Massachusetts male aging study. Diabetes Care 2000;23:490-4. DOI PubMed

73. Ottarsdottir K, Nilsson AG, Hellgren M, Lindblad U, Daka B. The association between serum testosterone and insulin resistance: a longitudinal study. Endocr Connect 2018;7:1491-500. DOI PubMed PMC

74. Buvat J, Maggi M, Gooren L, et al. Endocrine aspects of male sexual dysfunctions. J Sex Med 2010;7:1627-56. DOI PubMed

75. Boeri L, Capogrosso P, Ventimiglia E, et al. Sexual dysfunction in men with prediabetes. Sex Med Rev 2020;8:622-34. DOI PubMed

76. Rastrelli G, O'Neill TW, Ahern T, et al; EMAS study group. Symptomatic androgen deficiency develops only when both total and free testosterone decline in obese men who may have incident biochemical secondary hypogonadism: prospective results from the EMAS. Clin Endocrinol (Oxf) 2018;89:459-69. DOI PubMed

77. Filippi S, Vignozzi L, Morelli A, et al. Testosterone partially ameliorates metabolic profile and erectile responsiveness to PDE5 inhibitors in an animal model of male metabolic syndrome. J Sex Med 2009;6:3274-88. DOI PubMed

78. Ballester J, Muñoz MC, Domínguez J, Rigau T, Guinovart JJ, Rodríguez-Gil JE. Insulin-dependent diabetes affects testicular function by FSH- and LH-linked mechanisms. J Androl 2004;25:706-19. DOI PubMed

79. Vignozzi L, Morelli A, Filippi S, et al. Testosterone regulates RhoA/Rho-kinase signaling in two distinct animal models of chemical diabetes. J Sex Med 2007;4:620-32. DOI PubMed

80. Brüning JC, Gautam D, Burks DJ, et al. Role of brain insulin receptor in control of body weight and reproduction. Science 2000;289:2122-5. DOI PubMed

81. Khaw K, Barrett-connor E. Lower endogenous androgens predict central adiposity in men. Ann Epidemiol 1992;2:675-82. DOI PubMed

82. Pasquali R, Casimirri F, Cantobelli S, et al. Effect of obesity and body fat distribution on sex hormones and insulin in men. Metabolism 1991;40:101-4. DOI PubMed

83. Mårin P, Holmäng S, Gustafsson C, et al. Androgen treatment of abdominally obese men. Obes Res 1993;1:245-51. DOI PubMed

84. Mårin P, Holmäng S, Jönsson L, et al. The effects of testosterone treatment on body composition and metabolism in middle-aged obese men. Int J Obes Relat Metab Disord 1992;16:991-7. PubMed

85. Dhindsa S, Prabhakar S, Sethi M, Bandyopadhyay A, Chaudhuri A, Dandona P. Frequent occurrence of hypogonadotropic hypogonadism in type 2 diabetes. J Clin Endocrinol Metab 2004;89:5462-8. DOI PubMed

86. Dhindsa S, Ghanim H, Batra M, et al. Insulin resistance and inflammation in hypogonadotropic hypogonadism and their reduction after testosterone replacement in men with type 2 diabetes. Diabetes Care 2016;39:82-91. DOI PubMed PMC

87. Schlesinger S, Neuenschwander M, Barbaresko J, et al. Prediabetes and risk of mortality, diabetes-related complications and comorbidities: umbrella review of meta-analyses of prospective studies. Diabetologia 2021. DOI PubMed

88. Giagulli VA, Castellana M, Carbone MD, et al. Weight loss more than glycemic control may improve testosterone in obese type 2 diabetes mellitus men with hypogonadism. Andrology 2020;8:654-62. DOI PubMed

89. Ognjenovic M, Ambrosini GL, Malacova E, et al. Associations between major dietary patterns and testicular function in a populationbased cohort of young men: results from the Western Australian Pregnancy Cohort (Raine) Study. Andrology 2019;7:273-80. DOI PubMed

90. Grossmann M, Fui MNT, Nie T, et al. Changes in white adipose tissue gene expression in a randomized control trial of dieting obese men with lowered serum testosterone alone or in combination with testosterone treatment. Endocrine 2021;73:463-71. DOI PubMed

91. Steeves JA, Fitzhugh EC, Bradwin G, McGlynn KA, Platz EA, Joshu CE. Cross-sectional association between physical activity and serum testosterone levels in US men: results from NHANES 1999-2004. Andrology 2016;4:465-72. DOI PubMed PMC

92. Kanakis GA, Tsametis CP, Goulis DG. Measuring testosterone in women and men. Maturitas 2019;125:41-4. DOI PubMed

93. Krone N, Hughes BA, Lavery GG, Stewart PM, Arlt W, Shackleton CH. Gas chromatography/mass spectrometry (GC/MS) remains a pre-eminent discovery tool in clinical steroid investigations even in the era of fast liquid chromatography tandem mass spectrometry (LC/MS/MS). J Steroid Biochem Mol Biol 2010;121:496-504. DOI PubMed PMC 